\title{
STABILISASI TANAH DENGAN KAPUR DOLOMITE SEBAGAI LAPISAN PERKERASAN MENGGUNAKAN METODE PEMERAMAN
}

\author{
Varleen George Janis \\ Program Study Teknik Sipil Universitas Muhammadiyah Sorong \\ Jalan Pendidikan No 27 Kota Sorong, Propinsi Papua Barat \\ Email:varleenjanis@gmail.com
}

\begin{abstract}
ABSTRAK
Kabupaten sorong termasuk salah satu kabupaten yang cukup pesat perkembangan di provinsi Papua Barat. Kabupaten sorong semakin tumbuh dengan pesat, hal ini dapat dilihat dari semakin banyaknya pembangunan infrastruktu rseperti hunian, pusat pembelanjaan, dan kawasan komersil lainnya. Sebagai Distrik Mariat yang menjadi pusat kegiatan ekonomi di Kabupaten Sorong, tentunya akan menjadi daya Tarik bagi para imigran untuk tinggal dan menetap di distrik ini. Secara keseluruhan berdasarkan badan statistik kabupaten sorong 2013 kepadatan penduduk mencapai 5,41 jiwa $/ \mathrm{km}^{2}$. Distrik ke dua dengan penduduk terpadat yaitu distrik Mariat mencapai 10.920 jiwa atau sekitar 14,94 \% dari keseluruhan jumlah penduduk di kabupaten sorong. Dengan semakin meningkatnya usaha, pembangunan, dan pertambahan penduduk. Maka pembangunan jalan pun harus di tingkatkan. Jalan raya sebagai salah satu sarana lalu lintas menjadi kebutuhan penting, dan sudah selayaknya pemerintah daerah Kabupaten Sorong memprioritaskan hal ini. Kondisi jalan sangat berpengaruh terhada pkelancaran lalu lintas. Ada banyak hal yang dapat menyebabkan suatu ruas jalan menjadi rusak. Beberapa di antaranya seperti tidak adanya drainase yang memadai di sepanjang ruas jalan tersebut, beban lalulintas yang ada melebihi beban lalulintas yang diperkirakan, sampai pengerjaan proyek jalan yang dilakukan secaraasal-asalan. Selain itu, biaya untuk pembuatan jalan yang terbatas juga ikutmenyebabkansuatuperencanaanjalan yang ekonomis, sesuaidengankondisitanah dan beban lalulintas yang ada. Kekuatan tanah dasar merupakan hal yang penting dalam struktur jalan karena kekuatan tanah dasar akan menentukan perkerasan jalan yang dibutuhkan. Pada kenyataannya, kondisi tanah asli sangat bervariasi dan tidak semua jenis tanah layak dijadikan sebagai tanah dasar jalan raya.
\end{abstract}

KATA KUNCI : kabupaten sorong, stabilisasi tanah dengan kapur dolomite 


\section{PENDAHULUAN}

\section{Latar Belakang}

Kabupaten sorong termasuk salah satu kabupaten yang cukup pesat perkembangan di provinsi Papua Barat. Kabupaten sorong semakin tumbuh dengan pesat, hal ini dapat dilihat dari semakin banyaknya pembangunan infrastruktu rseperti hunian, pusat pembelanjaan, dan kawasan komersil lainnya. Sebagai Distrik Mariat yang menjadi pusat kegiatan ekonomi di Kabupaten Sorong, tentunya akan menjadi daya Tarik bagi para imigran untuk tinggal dan menetap di distrik ini. Secara keseluruhan berdasarkan badan statistik kabupaten sorong 2013 kepadatan penduduk mencapai 5,41 jiwa/ $/ \mathrm{km}^{2}$. Distrik ke dua dengan penduduk terpadat yaitu distrik Mariat mencapai 10.920 jiwa atau sekitar 14,94\% dari keseluruhan jumlah penduduk di kabupaten sorong. Dengan semakin meningkatnya usaha, pembangunan, dan pertambahan penduduk. Maka pembangunan jalan pun harus di tingkatkan. Jalan raya sebagai salah satu sarana lalu lintas menjadi kebutuhan penting, dan sudah selayaknya pemerintah daerah Kabupaten Sorong memprioritaskan hal ini. Kondisi jalan sangat berpengaruh terhada pkelancaran lalu lintas.

\section{Tujuan Penelitian}

1. Untuk mengetahui karakteristik tanah yang telah distabilisasi dengan kapur dolomite

2. Untuk menganalisa nilai $C B R$ tanah yang telah distabilisasi dengan kapur dolomite

\section{STATE OF THE ART}

Adapun penelitian terdahulu yang terkait dengan penelitian ini adalah sebagai berikut :

\section{Ikomang Tri Herdiana (2018)}

Penelitian tentang Stabilisasi Tanah lempung yang dicampur zat additive kapur dan matos ditinjau dari waktu pemeraman. Dari penelitian ini didapatkan hasil-hasil sebagai berikut :

1. Tanah yang diambil dari daerah Sidomulyo Kecamatan Sidomulyo, Kabupaten Lampung Selatan, Provinsi Lampung di klasifikasikan sebagai tanah lempung berplastisitas tinggi

2. Penggujian kapur dengan kadar $12 \%$ pada penelitian ini cukup efektif dalam meningkatkan daya dukung tanah yang di ambil dari daerah Sidomulyo. Karna mengalami peningkatan nilai CBR yang sangat baik.

3. Penggunaan matos pada penelitian ini sangat efektif untuk meningkatkan daya dukung tanah berplastisitas tinggi yang di ambil di daerah Sidomulyo, Kabupaten Lampung Selatan, Provinsi Lampung

4. Seiring dengan peningkatan variasi waktu perendaman yang dilakukan akan berpengaruh dengan penurunan nilai daya dukung tanah

5. Pemakaian matos sebagai bahan stabilisasi tanah lempung plastisitas tinggi menjadi salah satu alternative yang baik, karena dapat meningkatkan daya dukung tanah dan mempu mengalihkan gerak air horizontal terhadap tanah bukan vertical

\section{Ahmad Ibnu Asfian (2017)}

Penelitian tentang Stabilisasi Tanah Kabupaten Sorong Dengan Kapur Sebagai Lapisan Perkerasaan. Dari penelitian ini didapatkan hasil-hasil sebagai berikut :

1. Kondisi karakteristik tanah asli sebelum di campurkan dengan kapur yaitu kondisi tanah asli bersifat kohesif dan lunak oleh karena itu perlu adanya stabilisasi

2. Pengaruh tanah asli mariyat pantai dengan penambahan kapur dolomite akan menghasilkan campuran yang cenderung berbutir. Tanah dengan campuran kapur bersifat non-kohesif, sementara nilai CBR unsoaked-nya akan lebih tinggi jika dibandingkan dengan tanah asli tanpa campuran kapur. Kemudian kapur yang digunakan untuk stabilisasi ialah tanah yang lolos saringan No. 4 yang berdiameter $4,75 \mathrm{~mm}$ 
3. Penstabilan tanah asli untuk perkerasaan jalan dengan kapur setelah melaui proses pengujian labolatarium telah layak, dengan menghasilkan nilai CBR unsoaked campuran 6\% kadar kapur yang didapatkan kemudian langsung di uji nilai CBR-nya adalah sebesar 48,41\%.

4. Campuran tanah asli dan kapur yang paliing efektif ialah campuran dengan kadar kapur $6 \%$, kemudian hasil nilai CBR unsoaked pun lebih besar dari pada tanah asli. Hal ini yagn membedakan dengan penelitian sebelumnya oleh Teodore Ignatius Minaroy (2011) yang menyatakan bahwa hasil uji yang di dapat untuk pencampuran tanah dengan 10\% kadar kapur, nilai CBR unsoaked justru lebih kecil dari nilai CBR dibawah $10 \%$ pada lokasi yang berbeda

\section{Fitridawati Soehardi (2017)}

Penelitian tentang Pengaruh Waktu Pemeraman Stabilisasi Tanah Menggunakan Kapur Terhadap Nilai CBR. Dari penelitian ini didapatkan hasil-hasil sebagai berikut :

1. Material tanah berbutir halus digunakan termasuk jenis tanah lempung plastisitas rendah, termaksuk kelompok A-7-6, sesuai dengan klasifikasi tanah menurut AASTHO dan kelompok CL sesuai dengan Klasifikasi Tanah Menurut USCS

2. Kadar kapur optimum yang digunakan dalam proses campuran tanah lempung plastisitas rendah dengan kapur untuk pengujian laboratarium adalah sebesar $9 \%$ dari berat tanah

3. Terhadap periode siklus pada mekanisme durabilitas, ternyata bahwa pada periode siklus keempat, nilai CBR laborataruim campuran tanah plastisitas tanah dengan kapur mencapai 96\%, sehingga tidak memenuhi spesifikasi teknis minimal nilai CBR 100\%

4. Bila material tanah yang digunakan merupakan tanah dengan klasifikasi baik, maka stabilisasi tanah dengan semen atau kapur akan dapat berfungsi sebagai lapis pondasi pada struktur konstruksi jalan

5. Proses rendaman air pada mekanisme durabilitasi dapat menurunkan nilai CBR labolatarium (soaked CBR) terhadap pondasi yang menggunkan metoda stabilitas tanah semen atau kapur

6. Bila suatu daerah menggunakan metoda stabilisasi tanah dengan semen atau kapur sebagai lapis pondasi pada konstruksi jalan raya akan mengalami genangan air setiap tahun pada saat musim hujan, berarti bahwa pada tahun keempat, konstruksi lapis pondasi tanah tersebut, tidak dapat berfungsi dengan baik dan tidak memenuhi persyaratan teknis

7. Semakin lama durasi waktu lapis pondasi stabilisasi tanah dengan semen atau kapur akan tergenang air, maka nilai plastisitas akan mengalami peningkatan secara perlahan

8. Lama waktu pemeraman dan kadar kapur optimum akan mempengaruhi sifat plastisitas tanah, dimana nilai batas cair dan nilai indeks plastisitas akan mengalami penurunan 
METODE

Tahapan Penelitian

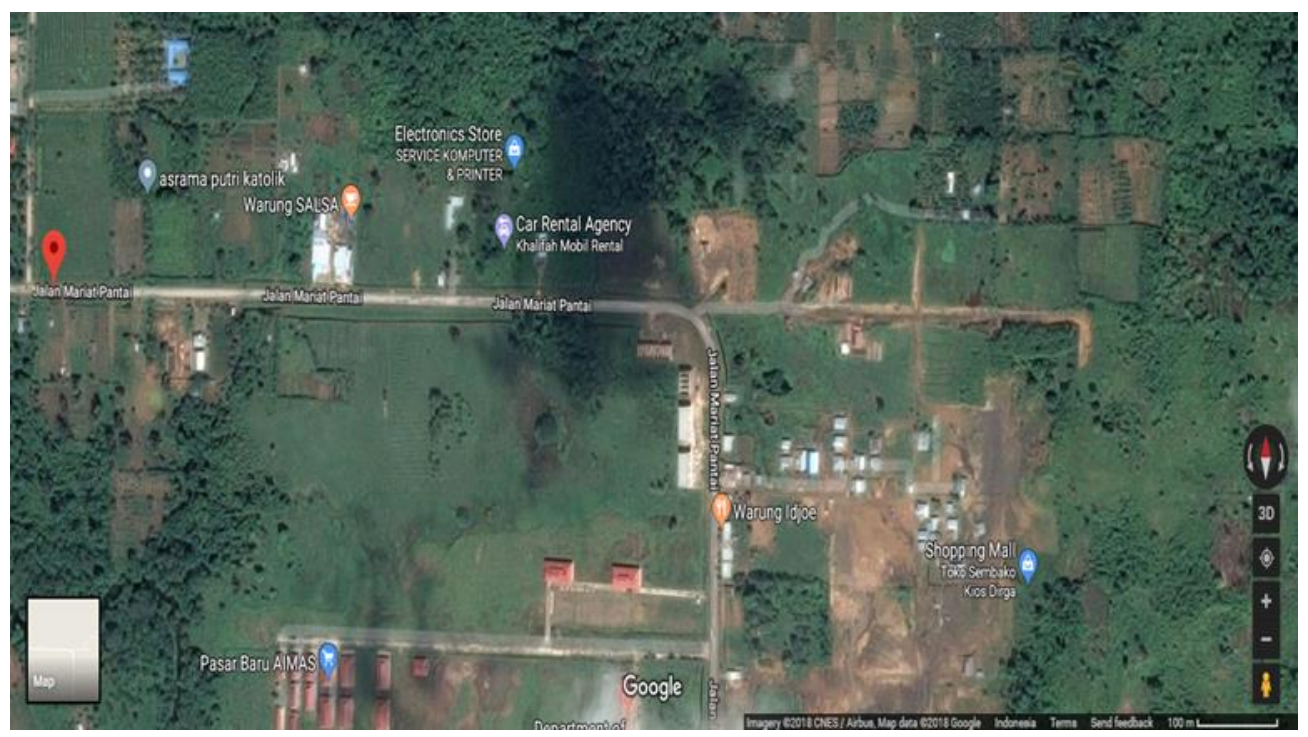

Tahapan penelitian yang digunakan adalah sebagai berikut :

1. Dari hasil pengujian percobaan analisis saringan dan batas atterberg untuktanah asli digunakan untuk mengklasifikasikan tanah berdasarkanklasifikasi tanah AASHTO

2. Dari data hasil pengujian pemadatan tanah untuk sampel tanah asli grafik hubungan berat volume kering dan kadar air untuk mendapatkan nilai kadar air kondisi optimum yang akan digunakan untuk membuat sampel pada uji CBR

3. Menyiapkan sampel tanah yang akan distabilisasi dan sampel tanah yangdigunakan merupakan sampel yang lolos saringan No. 4. Untuk masing-masingcampuran disiapkan sebanyak tiga sampel

4. Bawa sampel yang akan distabilisasi untuk OMC menggunakan air bersihdan tercampur menyeluruh, lalu tempatkan material dalam kantong plastik dan tutup

5. Melakukan pembuatan benda uji untuk pengujian CBR dengan mencampurkapur dan tanah yang telah lolos saringan no. 4

6. Variasi kadar kapur yang ditentukan yaitu 2\%, 4\%, 6\%, 10\% dan 12\%. Untukmasing-masing campuran disiapkan sebanyak 3 sampel untuk pemadatandengan modified proctor

7. Tempatkan tanah yang dicampur dengan kapur dalam kantongplastik, serta dalam kondisi lepas dan peram selama 7 hari

8. Setelah didiamkan selama 7 hari, tanah yang telah dicampur dengan kapurdipadatkan dengan 5 lapisan untuk pengujian CBR denganmemakai kadar air optimum tanah campuran dari modified proctor 


\section{REFERENSI}

1. Ikomang Tri Herdiana (2018). Stabilisasi Tanah lempung yang dicampur zat additive kapur dan matos ditinjau dari waktu pemeraman.

2. Ahmad Ibnu Asfian (2017). Stabilisasi Tanah Kabupaten Sorong Dengan Kapur Sebagai Lapisan Perkerasaan

3. Fitridawati Soehardi (2017). Pengaruh Waktu Pemeraman Stabilisasi Tanah Menggunakan Kapur Terhadap Nilai CBR.

4. Hardiyatmo, C.H. (2006). Mekanika tanah 1

5. Braja, M.D. (1993). "Mekanika tanah jilid 2 (prnsip pinsip rekayasa geoteknis)" UGM Yogyakarta

6. Ir. .ROKHMAN,MM. "Modul Praktikum Mekanika Tanah" Universitas Muhammadiyah Sorong

7. Pristianto, H., Amri, I., \& Rusdi, A. (2014, May 9). Pedoman Penulisan Tugas Akhir Fakultas Teknik Universitas Muhammadiyah Sorong 2014. http://doi.org/10.17605/OSF.IO/4VTJM. 